УДК: 377.36:37.091.313

\title{
КОНТРОЛЬ ТА ОЦІНЮВАННЯ РЕЗУЛЬТАТІВ ПРОЕКТНОЇ НАВЧАЛЬНОЇ ДІЯЛЬНОСТІ СТУДЕНТІВ КОЛЕДЖІВ І ТЕХНІКУМІВ
}

\author{
Тетяна Пащенко, \\ кандидат педагогічних наук, старший науковий співробітник, \\ стариий науковий співробітник \\ лабораторії науково-методичного супроводу \\ підготовки фахівиів у коледжах і технікумах \\ Інституту професійно-технічної освіти НАПН Украӥни
}

кЛЮЧОВІ
СЛОВА:
проектна діяльність
студентів
технікумів
коледжів,
оцінювання
результатів

\begin{abstract}
Постановка проблеми. Завдання сучасного професійного закладу освіти (технікуму, коледжу) - це виховання компетентної особистості, яка не лише володіє знаннями, високими моральними якостями, а й здатна самостійно, нестандартно, креативно діяти в різноманітних життєвих ситуаціях, застосовуючи свої знання, досвід і беручи на себе відповідальність за самостійний вибір форм і методів роботи.
\end{abstract}

Аналіз останніх досліджень. Багато науковців досліджують питання використання методу проектів у навчальному процесі. При вивченні проблем, пов'язаних 3 проектною діяльністю студентів, були визначені основні характеристики методу проектів та види проектів, здійснено опис реалізації їх у процесі навчання (I. Сергеєв, H. Gudjons, K. Frey, D. Fried-Booth, F. Stoller, W. Kilpatrick); розглянуті методичні аспекти застосування цієї технології (Г. Романова, Ю. Жиляєва, Д. Левітес); розроблено класифікацію проектів (S. Haines, H. Gudjons, Н. Коряковцева), досліджено використання методу проектів у професійній підготовці (Л. Липська, В. Черних); вивчено можливості методу проектів у формуванні навчально-пізнавальної самостійності студентів (В. Копилова, I. Степанова) та ін.

Аналіз спеціальної літератури i досвіду діяльності технікумів та коледжів свідчить про недостатню інтенсивність застосування творчих проектів у практиці роботи навчальних закладів. Причина нереалізованості проектної технології полягає в тому, що іï впровадження не підготовлене ні в організаційному, ні в технічному, ні, найголовніше, в особистісному, психологічному плані. Тому чітке розуміння змісту, критеріїв технології проектної діяльності, володіння методикою ііі застосування дає змогу як окремим учителям, так i керівникам навчальних закладів, об'єктивно оцінювати і прогнозувати ії впровадження.

Навчання 3 використанням проектних технологій має безумовні переваги, зокрема, створює умови для творчої самореалізації студентів, підвищує мотивацію для отримання знань, сприяє розвитку їхніх інтелектуальних здібностей. Студенти набувають досвіду вирішення реальних проблем 3 огляду на 
Тетяна Пащенко. Контроль та оцінювання результатів проектної навчальної діяльності студентів коледжів і технікумів

майбутнє самостійне життя, яке проектують у навчанні. Водночас, застосування означеної технології на практиці має низку проблем, серед яких - питання, пов'язані 3 контролем та оцінюванням навчальних проектів.

Мета статті - охарактеризувати методичні аспекти контролю та оцінювання групової проектної діяльності студентів.

Виклад основного матеріалу. Будь-яка робота над темою чи просто групова робота ще не $€$ методом проектів. Останній передбачає певну сукупність навчально-пізнавальних прийомів, що дають змогу вирішити ту чи іншу проблему шляхом самостійних дій студентів 3 обов'язковою презентацією (представленням, викладенням) отриманих результатів.

Для подання результатів роботи у проекті можна розробити презентацію або текстовий документ, розмістити отримані матеріали на сайті чи блозі, або вибрати інші засоби. У презентації важливо відобразити весь хід роботи: завдання, що були поставлені, методи пошуку та опрацювання використаних матеріалів, отримані результати та висновки.

Презентація повинна відповідати навчальним цілям проекту, допомагати в розкритті поставлених у проекті питань. Вона не повинна бути великою i нагадувати інформаційний довідник 3 обраної теми. Презентація має відображати дослідницьку діяльність студентів у навчальному проекті, оскільки використовувати ऑiі необхідно для наочного подання результатів своєї самостійної діяльності. При розробці форм та критеріїв оцінювання презентації увагу необхідно звертати на зміст, грамотність викладу матеріалу, достовірність інформації, оформлення та взаємодію студентів у процесі роботи.

Презентація дає можливість подати матеріал більш наглядно, індивідуально, 3 використанням елементів якісної графіки, відеоматеріалів, звуковим супроводом. Використання комп'ютерних презентацій сприяє розвитку наочно-образного мислення, стійкості уваги, образної пам'яті, уважності, спостережливості, стимулює продуктивні творчі функції мислення. У процесі створення презентації студенту необхідно проявити себе сценаристом, режисером, художником і вимогливим глядачем.

Публікація повинна створюватися 3 урахуванням віку аудиторії, на яку вона розрахована, i, відповідно, змісту, що їй притаманний. Необхідно ретельно продумати, яким чином можна досягнути поставлених навчальних цілей. Для цього варто розробити спочатку схему планування іiі змісту та структури.

При оцінюванні публікації бажано звертати увагу на те, чи вносить вона якісь якісні зміни до навчального процесу, наскільки ефективно використовувалися при цьому комп'ютерні технології, чи сприяє вона формуванню у студентів навичок мислення високого рівня.

Після перегляду публікації необхідно іiі проаналізувати, визначити, в чому іiі сильні сторони, чи відображається зв'язок між використанням комп'ютерних технологій та одержанням нових знань i навичок. Варто встановити, яким чином вона демонструє уміння студентів інтерпретувати, оцінювати, узагальнювати, аналізувати інформацію, чи свідчить про розуміння поставлених навчальних цілей, i взагалі, чи відповідає розробленим критеріям оцінювання.

Для встановлення зв'язку 3 іншими студентами у світі доцільно створювати вебсайти. Вони слугують водночас i засобом пошуку партнерів для здійснення завдань проекту, й інформаційними ресурсами для інших студентів. Веб-сайти можна використовувати для демонстрації процесу навчання, для опублікування результатів анкетних опитувань, для подання студентських робіт, висвітлення результатів проекту, відображення подій із життя групи чи навчального закладу.

Веб-сайт цікавий тим, що дає змогу зробити багато гіперпосилань на матеріали, які ми не бачимо, потрапивши на ту чи іншу сторінку. Доцільно і корисно після завершення роботи обговорити створений веб-сайт.

Завершальним етапом роботи у проекті $\epsilon$ його захист. Важливо не тільки подати опис проекту та хід його виконання, але й відобразити участь кожного із членів групи у проекті. Отже, у виступі мають бути названі: назва і цілі проекту; засоби, методи і шляхи, що були обрані для реалізації проекту; 3 якими труднощами і проблемами зустрілися учасники проекту в ході його реалізації; результати проекту; висновки, зроблені на основі результатів проекту; наскільки вдалося досягти мети проекту.

Загальновідома презентація формату PowerPoint вже давно $є$ допоміжним засобом візуалізації навчального матеріалу, але ії можна віднести до стандартних. Зовсім нещодавно в навчальному середовищі почали зустрічатися слова «скрайбінг», «скрайб», «скрайбер», що $є$ складниками скрайб-технології. Скрайбінг (від 
англ. Scribe - «розмічати») - нова техніка презентації, винайдена британським художником Ендрю Парком для британської організації наукових знань.

Доповідь спікера супроводжується ілюстраціями «на льоту» малюнків фломастером на білій дошці. Таким чином, слухачі чують і бачать одночасно приблизно одне й те ж саме, що полегшуе сприйняття інформації. Це, насамперед, мистецтво відображати своє мовлення в малюнках, причому, процес відбувається в реальному часі, паралельно 3 доповіддю мовця. Скрайбпрезентація відображає ключові поняття розповіді та взаємозв'язок між ними. Наразі скрайбінг - інноваційна технологія, за допомогою якої можна привернути увагу слухачів, забезпечити ї додатковою інформацією та виокремити головні моменти доповіді. Крім того, проглядати скрайб (зображення, що з'являється з-під пера, ручки, маркера) набагато цікавіше, ніж звичайне відео. Скрайбінг має багато переваг, що допоможе урізноманітнити подачу матеріалу, зацікавить студентів, полегшить сприйняття інформації. Серед «плюсів» цієї технології можна виділити такі: участь та увага аудиторії; якісне засвоєння інформації та запам'ятовування ключових моментів; зручне сприйняття інформації; можливість безперервного спілкування зі слухачами [5].

Основні завдання контролю - виявлення рівня правильності, об'єму, глибини і дієвості засвоєних студентами знань, отримання інформації про характер пізнавальної діяльності студентів в навчальному процесі, визначення ефективності методів, форм і засобів навчання.

Процес оцінювання проектної діяльності студентів, як і будь-якої навчальної діяльності взагалі, i проектної зокрема, передбачає реалізацію таких функцій:

- навчальна функція, що зумовлена зворотним зв'язком як передумовою підтримання дієвості й ефективності процесу навчання, в якому беруть участь два суб'єкти викладач і студент, і за цієї умови система навчання може функціонувати ефективно лише з дотриманням дії прямого і зворотного зв'язків;

- діагностична функція суть якої полягає у виявленні прогалин у знаннях студентів, тому важливо своєчасно виявити недоліки, працювати над їх усуненням;

- стимулююча функція аналізу й оцінювання навчальної діяльності студентів зумовлюється психологічними особливостями людини, що виявляється в бажанні особистості отримати оцінку результатів своєї діяльності, зокрема навчальної. Викладач повинен допомогти студентам усвідомити якість i результативність навчальної праці, що психологічно стимулює їх до активної пізнавальної діяльності;

- виховна функція полягає у впливі аналізу й оцінки навчальної діяльності на формування у студентів низки соціально-психологічних якостей: організованості, дисциплінованості, відповідальності, сумлінності, працьовитості, дбайливості й охайності, наполегливості тощо.

- розвивальна функція виявляється в тому, що студент, отримавши оцінку, відчуває бажання й потребу в активізації пізнавальної діяльності, це стимулює особистість до розвитку психічних властивостей і процесів волі, уваги, мислення, мовлення тощо;

- коригувальна функція полягає в тому, що на основі виявленого рівня знань, умінь i навичок, утруднень, недоліків, причин неуспішності вживаються заходи щодо їх усунення;

- прогностична функція, в результаті реалізації якої викладач отримує дані для оцінки результатів своєї праці, методики, для подальшого їх удосконалення; оцінювання результатів навчальної діяльності студента допомагає йому скоригувати, поліпшити свою навчальну роботу;

- контролююча функція дає можливість визначити і співвіднести рівень знань, умінь, навичок студента 3 вимогами навчальної програми, забезпечити об'єктивність оцінювання, підготуватися до засвоєння нового навчального матеріалу.

Крім того, важливим моментом оцінювання $\epsilon$ те, що воно реалізується при дотриманні принципів, суть яких полягає: в плановості (аналіз і оцінювання мають здійснюватися не стихійно, а 3 дотриманням певного плану), систематичності й системності (аналіз і оцінювання мають відповідати структурним компонентам змісту вивченого матеріалу і бути постійними), об'єктивності (аналіз і оцінювання мають бути науково обгрунтованими i базуватися на засадах гуманізму i демократизму), відкритості й прозорості (студенти мають знати свої оцінки й оцінки однокурсників, що давало би змогу порівнювати успіхи, стимулювало б до підвищення активності), економічності (методи, прийоми, зміст завдань мають бути співвідносними 3 наявним бюджетом часу студентів, а методи - 
Тетяна Пащенко. Контроль та оцінювання результатів проектної навчальної діяльності студентів коледжів і технікумів

ще й доступними і зрозумілими), тематичності (перевірка якості знань студентів з окремих тем, розділів проводиться за темами, блоками, модулями); врахування індивідуальних можливостей студентів [1].

За умов рейтингового підходу пропонується для оцінки проектної діяльності застосовувати 10 критеріїв, 3 них 5 критеріїв виконання, і 5 критеріїв - захисту проекту [4].

Аналіз результатів роботи студентів, які виконують проект, потрібно спрямувати за двома напрямами: спеціальному і загальному. Спеціальний аналіз має за мету з'ясувати, вдало чи невдало виконаний той чи інший проект (або його частина), і якщо невдало, то з'ясувати причини. Загальний аналіз має на меті 3'ясування помилок загального характеру, наприклад, неохайність у технічному виконанні, незначне відхилення від наміченого плану тощо [3].

П. Лернером запропоновані такі критерії оцінювання результатів виконаних проектів:

- аргументованість вибору теми, практична направленість проекту і значимість виконаної роботи;

- обсяг і повнота розробок, виконання прийнятих етапів проектування, самостійність, підготовленість до сприйняття проекту іншими людьми, його матеріальне втілення;

- аргументованість запропонованих рішень, підходів, висновків, повнота бібліографії;

- рівень творчості, оригінальність теми, підходів, знайдених рішень, аргументів, що пропонуються; своєрідність матеріального втілення і представлення проекту;

якість пояснювальної записки: оформлення, відповідність стандартним вимогам, рубрикація і структура тексту, якість ескізів, схем, малюнків; якість і повнота рецензій;

- якість виробу, відповідність стандартам, оригіна льність [2].

Критерії оцінювання мають стати для студентів надійною керівною основою для забезпечення справжньої реалізації цілей проекту. Це можливо тільки за таких умови, коли: критерії оцінювання будуть розроблятися лише після вибору мети всього проекту; заздалегідь повідомлені студентам; будуть максимально підтримуючими, стимулюючими повну (різнобічну) роботу за темою проекту; критерії оцінювання сприятимуть творчості студентів, і їх буде достатньою.

Кожен із критеріїв оцінювання проектної діяльності передбачає певну кількість балів, це залежить від шкали оцінювання, що використовується. Оцінка включає в себе бал, тобто цифрову або іншу символічну форму вираження та фіксації оцінювання успішності за даними критеріями.

Отже, для того, щоб підвищити ефективність навчального процесу і забезпечити об’єктивність оцінювання проектної діяльності студентів, необхідно проводити оцінювання на кожному етапі проектної діяльності 3 дотриманням виділених критеріїв.

Дуже важливо, щоб контроль знань, умінь та навичок був не епізодичним, а систематичним i регулярним. Систематичність контролю $є$ важливим психологічним фактором, який організовує й дисциплінує студентів, створює постійну трудову атмосферу, формує потребу в праці, наполегливість і спрямованість у досягненні мети. Регулярний контроль сприяє виробленню в студентів навичок самоконтролю, вміння аналізувати свою

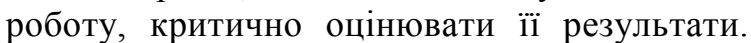
Без систематичного контролю за засвоєнням студентами знань, навичок та вмінь неможливо правильно організовувати навчально-трудовий процес, забезпечити його ефективність.

У ході роботи над проектом студенти неодноразово можуть звертатися до критеріїв оцінювання їхньої навчальної діяльності. Для цього готуються тести, контрольні запитання, розробляються форми оцінювання презентацій, публікацій, веб-сайтів тощо. При цьому варто зауважити, що дуже добре, якщо студенти знають, хто, коли та на якому етапі буде оцінювати їхню роботу. Оцінювання може проводитися учителями, групами студентів або кожним студентом окремо.

Проектна діяльність - це особливий вид діяльності, що вимагає самоконтролю й самоаналізу, які проявляються в самостійній роботі студента. До критеріїв уміння виконувати самостійну роботу можна віднести: вміння планувати, вибирати форми, методи i прийоми діяльності, раціонально організовувати свою діяльність, враховувати результати й коригувати подальші дії, бачити іiі перспективи та кінцевий результат.

Висновок. Проектна діяльність як особливий вид діяльності потребує самоконтролю й самоаналізу, які проявляються в самостійній роботі студента. Завершальним етапом роботи у проекті $\epsilon$ його захист. Під час захисту учасники проекту звітують про результати реалізації проекту. Дуже важливо, щоб контроль знань, умінь та навичок був не 
епізодичним, а систематичним і регулярним. Оцінювання не має складатися тільки 3 оцінки педагога, а враховувати самооцінку i взаємооцінку учасників проекту, зовнішню експертну оцінку. Треба пам'ятати й про заохочувальну роль оцінювання у проектній діяльності.

\section{Література}

1. Алексюк А.М. Педагогіка вищої школи. Курс лекцій: модульне навчання. Навч. посібник / А.М. Алексюк - К. : ІСДО, 1993. - 220 с.

2. Лернер П. Проектування як основний вид пізнавальної діяльності школярів / П. Лернер // Завуч. - 2003. - № 7. - С. 6-10.

3. Сасова И. Через проблему - к практическому результату / И. Сасова // Учитель. 2001. - № 5. - C. 35-38.
4. Чечель И. Метод проектов: субъективная и объективная оценка результатов / И. Чечель // Директор школы. - 1998. - № 4. - С. 3-10.

5. Сорока Т. В. Скрайбінг як сучасна форма візуалізації навчального матеріал у/ Т. В. Сорока // Нове в практику. - 2015. - № 15-16 (283-284).- C. 60-62.

\section{Реферат}

\section{Контроль и оценка результатов проектной учебной деятельности студентов колледжей и техникумов}

Татьяна Пащенко, кандидат педагогических наук, старший научный сотрудник, стариий научный сотрудник лаборатории научно-методического сопровождения подготовки специалистов в колледжах и техникумах Института профессионально-технического образования НАПН Украинь

\section{КЛЮЧЕВЫЕ СЛОВА: \\ проектная деятельность студентов техникумов и колледжей, оценка результатов, образование, проектная технология, обучение}

\begin{abstract}
В статье осуществлен анализ методических аспектов контроля и оценки групповой проектной деятельности студентов. Получение в учебном заведении теоретических знаний сегодня рассматривается условием необходимым, но недостаточным для удовлетворения требований рынка труда. Акценты заметно сместились в сторону формирования способностей применения знаний на практике с высоким уровнем самостоятельности и ответственности. Одной из учебных технологий, обеспечивающих определенный баланс между академическими знаниями и прагматическими умениями, и является метод проектов. Анализ специальной литературы и опыта деятельности техникумов и колледжей свидетельствует о недостаточной интенсивности применения творческих проектов в практике работы учебных заведений. Причина нереализованности проектной технологии заключается в том, что ее внедрение не подготовлено ни в организационном, ни в техническом, ни, самое главное, в личностном, психологическом плане. Поэтому четкое понимание содержания, критериев технологии проектной деятельности, владение методикой ее применение позволяет как отдельным учителям, так и руководителям учебных заведений, объективно оценивать и прогнозировать ее внедрения. Исследованием установлены основные принципы контроля знаний студентов во время проектно-технологической деятельности, рассмотрены функции, реализация которых предусматривает процесс оценки проектной деятельности студентов по любой учебной деятельности вообще, и проектной в частности.
\end{abstract}

Проектная деятельность - это особый вид деятельности, который требует самоконтроля и самоанализа, которые проявляются в самостоятельной работе студента. Завершающим этапом работы в проекте является его защита. Во время защиты участники проекта отчитываются про результаты реализации проекта. Очень важно, чтобы контроль знаний, умений и навыков был не эпизодическим, а систематическим и регулярным. Оценивание не должно состоять только из оценки педагога, а нужно учитывать самооценку и взаимооценку участников проекта, внешнюю экспертную оценку. Нужно помнить и о поощрительной роли оценки в проектной деятельности. 
Тетяна Пащенко. Контроль та оцінювання результатів проектної навчальної діяльності студентів коледжів і технікумів

\title{
Abstract \\ Control and assessment of colledge and technical students' project training results
}

\author{
PhD, Senior researcher, \\ Senior researcher at the Laboratory of scientific and methodological support \\ for specialists' training at colleges and technical schools \\ the Institute of vocational education and training \\ of the National academy of educational science of Ukraine
}

Tetyana Pashchenko,

\section{KEY WORDS: \\ technical schools and colleges students' project activity, results assessment, educational, project technology, training}

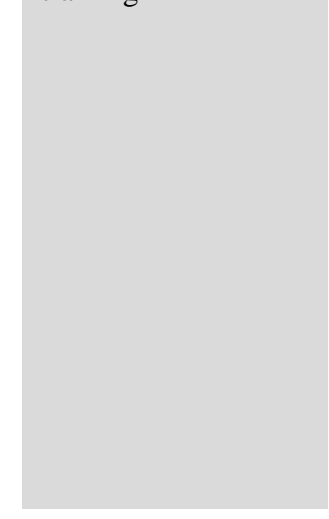

The article analyzes monitoring and evaluation methodological aspects of a group of students' project activities. Today the acquiring of theoretical knowledge at a training institution is considered a necessary condition, but not the sufficient one, to meet labour market demands. The emphasis has shifted significantly towards forming the ability to apply knowledge in practice performing high level of self-dependence and responsibility. The training technology for providing clearly stated academic knowledge and pragmatic skills balance is the method of projects. The analysis of professional literature and technical schools and colleges experience demonstrates the lack of creative projects active use within training institutions practice of educational institutions. The source for design technology outstanding is in lack of implementation management, technical aspects, or, most importantly, personal, psychological terms. Therefore, clear understanding of the content, technology criteria, methodology knowledge allows both individual teachers and heads of educational institutions to put in perspective and predict its implementation. The research establishes the basic students' knowledge monitoring principles while their project-technological activities, examines functions those foresee student's project activity assessment in any educational activity and project one specifically.

Project activity is a special kind of activity that requires self-control and self-analysis which are manifested in student's independent work. The final stage of the project is its critical review when students report on the results of its implementation. It is very important to conduct systematic and regular control of knowledge, skills and abilities. Evaluation should not consist only of a teacher's assessment, but include self-assessment and project participants' mutual evaluation, external peer review. It is necessary to remember the encouraging role of evaluation within project activities.

\section{References}

1. Aleksyuk A.M. PedagogIka vischoyi shkoli. Kurs lektsiy: modulne navchannya. Navch. posibnik / A.M. Aleksyuk. - K. : ISDO, 1993. - 220 s.

2. Lerner P. Proektuvannya yak osnovniy vid piznavalnoyi diyalnosti shkolyariv / P. Lerner // Zavuch. - 2003. - № 7. - S. 6-10.

3. Sasova I. Cherez problemu - $\mathrm{k}$ prakticheskomu rezultatu / I. Sasova // Uchitel. 2001. - № 5. - S 35-38.
4. Chechel I. Metod proektov: sub'ektivnaya i ob'ektivnaya otsenka rezultatov / I. Chechel // Direktor shkolyi. - 1998. - № 4. - S. 3-10.

5. Soroka T. V. SkraybIng yak suchasna forma vIzualIzatsIYi navchalnogo material / T. V. Soroka // Nove v praktiku. - 2015. - № 15-16 (283-284).S. 60-62. 